\title{
POLITIK DAN “TEATER RITUAL” DI BALI
}

\author{
I Ngurah Suryawan \\ Universitas Negeri Papua \\ e-mail: suryawan@yahoo.co.id
}

\begin{abstract}
The relation between ritual and socio-political environment should become a deep reflection. Rituals which take place in order for salvation, harmony, and natural balance instead generate the ambigue and ironic situation. Rituals had been going on amazingly but the social as well as natural disasters seems go on continually. In Bali, religious rituals that formerly guarded by mantra-mantra (spiritual wordings) recently enstead by a group of Pecalang (tradition guardian in Bali) and metal detector (at the time of Pamarisudha Karipubhaya Bali Blast of 2002 and 2005). Nowadays Balinese are eager to perform rituals spectacularly. But instead, Bali now is struck by continous disaster, not only the disaster came from external sources but also the internal ones.

Hubungan antara ritual dengan lingkungan sosial politik harus menjadi bahan renungan yang dalam. Ritual yang dilakukan untuk tujuan keselamatan, harmoni, dan keseimbangan alam bahkan menimbulkan kondisi ambigue dan ironis. Ritual berjalan secara mengesankan namun bencana sosial maupun bencana alam terus menerus terjadi. Di Bali, ritual agama yang sebelumnya diwarnai mantra-mantra kini diisi oleh Pecalang (pengawal tradisi Bali) dan metal detector (pada saat Pamarisudha Kariphaya Bom Bali 2002 dan 2005). Kini orang Bali cenderung melaksanakan ritual secara spektakuler. Akan tetapi Bali seringkali didera bencana, baik bencana yang berasal dari dalam maupun luar.
\end{abstract}

Keywords: $\quad$ ritual, disaster, mantra, pecalang, harmoni 


\section{A. Pendahuluan}

Tidak ada yang menyangkal bahwa Bali adalah bumi ritual. Bagi sebagian kalangan, dengan ritual yang beragam dan menyejarah, Bali menjadi bumi yang bersinar. Maka, ritual pun tidak henti-henti dilakukan dengan keyakinan teologis mampu mendamaikan alam dan isi bumi ini, khususnya di Bali. Sebagian kalangan lain berpendapat-khususnya dari kalangan pariwisata-ritual bisa menjadi salah satu potensi untuk menggerakkan "wisata ritual". Oleh sebab itulah, ritual dirancang untuk dipertontonkan kepada wisatawan dalam paket wisata. Tidak salah memang, namun serangkaian kemegahan ritual sebenarnya sangat problematik. Di dalamnya terhadap begitu besar silang relasi, yang mementaskan berbagai macam kepentingan dalam sebuah teater yang disebut dengan ritual.

Dalam perspektif teologis, ritual selalu berhubungan dengan bagaimana manusia menuju keseimbangan hubungan antara manusia dengan sesamanya, lingkungan, dan Tuhan-nya. Dalam perspektif teologis Hindu Bali sering disebut dengan Tri Hita Karana. Media dan ekspresi menuju keseimbangan itulah yang menempatkan ritual menjadi kegiatan sentral dalam kehidupan beragama khususnya. Maka tidaklah heran jika kemudian ritual dianggap menjadi basis kearifan kehidupan masyarakat dengan mengkaitkannya dengan nilai-nilai teologi agama. Tentunya ini tidaklah salah, namun praktik ritual sering tidak membumi dengan kehidupan kontekstual rakyatnya.

Ritus, ritual, upacara adalah agama dalam tindakan untuk mencari jalan keselamatan (salvation). Keselamatan adalah tujuan dari kehidupan beragama dan juga dari serangkain ritual yang dilakukan oleh agama-agama. ${ }^{1}$

Agama praksis yang terdapat dalam ritual menjadi cermin dari serangkaian aktivitas pendukung ritus tersebut. Ritual, upacara, dan ritus-ritus yang dilakukan pemeluk agama pasti mempunyai mitos tertentu. Selain itu dalam ritual terdapat hubungan erat antara mitos, suatu dongeng suci dari suatu bangsa dengan aktivitas ritual, tingkah laku moral, organisasi sosial, bahkan aktivitas politik suatu masyarakat. ${ }^{2}$

1 Suhardi, "Ritual: Pencarian Jalan Keselamatan Tataran Agama dan Masyarakat Perspektif Antropologi," Pidato Pengukuhan Guru Besar Antropologi pada Fakultas Ilmu Budaya Universitas Gadjah Mada, 18 Maret 2009, h. 13.

2 Dhafamony, Mariasusai, Fenomenologi Agama, (Yogyakarta: Kanisius, 1995); Malinowski dalam Suhardi, “Ritual: Pencarian Jalan Keselamatan....”, h. 12. 
Kategori ritual yang sering digunakan adalah ritual sekuler, semireligius, dan ritual agama. Ritual sekuler, profan dianggap berfungsi sosial politik seperti parade, karnaval, pelantikan pejabat, peringatan hari besar dan lainnya. Jenis ritual ini bertujuan secara implisit untuk mempertebal sentimen masyarakat dan kesadaran politik. Ritual semi-religius adalah ritual lingkaran hidup manusia seperti pawiwahan (perkawinan), metatah (potong gigi), menek kelih (ritual beranjak dewasa dalam tradisi Hindu Bali). Ritual jenis ini-menurut Tremmel-mempunyai tujuan sekuler, tetapi juga secara jelas dan pada hakikatnya didasarkan pada sesuatu yang disakralkan. ${ }^{3}$ Sementara ritus agama adalah upaya yang sungguh-sungguh berupaya untuk mencari jalan keselamatan jiwa melalui pola peribadatan dengan tujuan utama menjalin komunikasi antara manusia dengan alam transenden. Ketiga kategori ritus itu pada hakikatnya menempatkan manusia dan lingkungannya sebagai agency terpenting yang menggerakkan ritus tersebut. Dalam ritual yang sering dilakukan, transformasi dan beragam kepentingan yang menjalankan ritus menjadi poin yang sangat penting. Oleh karena itu ritus dengan berbagai mitos, aturan serta pelaksanaannya bisa berubah.

Di Bali, keterputusan hubungan itu terasa nyata sekali. Ritual di satu sisi berlangsung tanpa henti, namun sering melupakan konteks sosial masyarakatnya yang masih terjerat kemiskinan dan problematika hidup keseharian. Ritual hadir bukannya memberikan solusi dari kondisi sosial masyaratnya, namun malahan membebani kehidupan masyarakat. Situasi ini sungguh ironis melihat begitu mulia dan luhurnya cita-cita dari ritual.

Relasi ritual dengan lingkungan sosial politik seharusnya menjadi refleksi yang mendalam. Berbagai ritual-ritual yang berlangsung dengan tujuan untuk mencari keselamatan (salvation), harmonisasi serta keseimbangan alam justru melahirkan situasi yang ironis dan ambigu. Ritual berlangsung gemuruh sementara rentetan bencana seolah tidak henti mendera kehidupan manusia. Dharma Palguna mengungkapkan bagaimana "ritual-ritual agama" di Bali dulunya dijaga dengan mantra-mantra kini justru dijaga oleh sepasukan pecalang (barisan pengamanan adat di Bali) dan pemeriksaan metal detector (saat ritual Pamarisudha Karipubhaya Bom Bali

${ }^{3}$ Suhardi “Ritual: Pencarian Jalan Keselamatan...," h. 13. 
2002 dan 2005)..4 Orang-orang Bali kini gencar dan bersemangat melakukan berbagai macam ritual dengan megah dan spektakuler. Tapi justru saat itu pula rangkaian bencana sambung menyambung tanpa henti mendera Bali. Bukan hanya bencana yang datang dari luar, namun juga bencana dari dalam masyarakat Bali sendiri.

Ritual salah satunya mempunyai sifat yang rahasia (rahasya), jauh dari keramaian, bunyi-bunyian dan bau-bau yang tidak relevan. Jumlah orang yang ada dalam lokasi ritual juga terbatas dan lingkungan ritual juga telah dijaga secara mistis (sengker). Tujuannya agar pikiran buruk tidak masuk dalam lingkaran mistis (sesengkeran) sehingga tujuan ritual menjadi berhasil (tepet). Namun, orang-orang Bali kini tidak menghiraukan kerahasiaan, sekaralan ritual tersebut. Ritual dibuat menjadi event keramaian. Semakin ramai semakin membanggakan. ${ }^{5}$ Maka ada pertunjukan, ada jamuan, ada undangan untuk pejabat pemerintah yang menyerahkan sumbangan dan membuka ritual. Para pejabat ini biasanya akan didaulat untuk peletakan batu pertama jika ada ritual pembangunan pura, mendem pedagingan (meletakkan sesaji di bawah tanah) saat ritual peresmian pura berlangsung yang semestinya dilakukan oleh pendeta atau pemangku. Ritual tambah megah dan tinggi statusnya jika ada pemberitaan di media massa dan elektronik, dimuat dalam durasi 30 menit oleh stasiun TV lokal Bali TV dalam program Nangun Yadnya (menyambut ritual keagamaan).

Konteks yang diungkapkan oleh Dharma Palguna sejalan dengan apa yang diungkapkan oleh Dhafamony yang mengungkapkan bahwa ritual, upacara bukan ditanamkan dengan rasionalitas melalui rasionalisasi-rasionalisasi, namun perilaku ritual lebih bersifat simbolik. Dari pelaksanaan ritual diharapkan sesuatu perubahan dari manusia menuju situasi yang "agamais" atau menuju yang "kudus". Manusia diharapkan bertransformasi menuju situasi yang "lain sama sekali." 6

Namun, konteks ritual menuju transformasi manusia yang "agamais" melupakan bahwa konteks selain sebagai praktik keagamaan juga menyiratkan relasinya dengan kehidupan sosial politik ketika ritual berlangsung.

4 Dharma Palguna, IBM., Bom Teroris dan "Bom Sosial," Narasi dari Balik Harmoni Bali: PerspektifKorban dan Relawan, (Denpasar: Yayasan Kanaivasu, 2006).

5 Ibid., h. 150-151.

${ }^{6}$ Dhafamony, Mariasusai, Fenomenologi Agama..., h. 183. 
Ritual kematian di Bali misalnya bukan hanya persoalan lepasnya "badan kasar" dari "badan halus" serta bersatunya jasad manusia ke alam pertiwi, paramaatman (menyatunya atma dengan paramataman, Ida Sang Hyang Widhi Wasa, Tuhan Yang Maha Esa), namun seperti dipertanyakan oleh Santikarma ${ }^{7}$ berakhirnya hidup di Bali juga persoalan sosial yang berhubungan dengan soal status. Upacara kematian memunculkan argumentasi seperti, sejauh mana besar skala upacara? Siapa yang memimpin upacara, pendeta brahmana atau bukan? Berapa tinggi usungan jenazah? Bagi mereka yang anggota keluarganya raib akibat pembantaian massal 1965 kekisruhan muncul dalam menentukan status kematian: apa kematian mereka dianggap sebagai salahpati (bunuh diri) atau ulahpati (kecelakaan)? Keputusan ini nanti berpengaruh terhadap rangkaian sarana sesajen atau banten yang akan dipakai.

Ritual Atma Papa adalah salah satu ritual ngaben (pembakaran jenazah), ritual pembersihan terhadap orang-orang Bali yang belum diupacarai yang menjadi korban dari pembantaian massal 1965 dan bencana alam yang belum diupacarai oleh keluarganya. Karena jasadnya tidak ditemukan, maka jasad hanya disimbolkan dalam sawa/adegan dari janur/lontar yang diberi simbol kelamin laki-laki dan perempuan.

Artikel ini berusaha untuk memberikan gambaran sisi lain dalam melihat ritual sebagai sebuah medium pembebasan manusia jika kontekstual dengan kehidupan umat pengikutnya. Untuk menguraikan hal itu, melihat perspektif sosial dan politik yang membingkai ritual tentunya menjadi sangat penting. Artikel ini berusaha memberikan gambaran tentang relasi politik dan ritual, jaringan kepentingan yang bermain dalam pentas ritual dan juga bagaimana manipulasi ritual dan kebudayaan dipraktikkan untuk kemegahan dan glamournya ritual. Dengan menggunakan kasus ritual Atma Papa artikel ini berusaha melacak pentas politik ritual yang dipraktikkan di Bali.

\section{B. Ritual Atma Papa, Pembersihan, dan Keseimbangan}

Seorang nenek, rambutnya mulai memutih, duduk berderet di jalanan bersama ratusan orang lainnya. Dengan berpakaian adat Bali, selendang yang 2003.

7 Santikarma, Degung, "Monumen, Dokumen dan Kekerasan Massal," Kompas, 1 Agustus, 
menyelimuti rambutnya untuk menahan panas, menampakkan keseriusannya mengikuti upacara di catus pata, perempatan jalan di Kota Singaraja, Kabupaten Buleleng utara kota Denpasar. Sama dengan si nenek tadi, peserta lainnya berderet di bawah tenda sewaan. Dari mulai yang lanjut usia, sampai dengan anak muda dengan rambut disemir dan anting di telinga. Mereka rela berderet menahan panas, berdesakan. Yang mereka lakukan hanya memangku adegan/sawa, personifikasi simbol roh yang telah mati, dengan wujud janur dan kain putih kuning.

Siang itu, tanggal 7 September 2004, cuaca memang sangat panas. Di depan ratusan orang yang memangku adegan/sawa itu, terpampang spanduk upacara ritual tersebut, "Upacara Atma Papa Kabupaten Buleleng, 7 September 2004, Catus Pata Singaraja. Majelis Desa Pakraman Buleleng dan Pemda Buleleng".8 Sapanduk itulah yang melatarbelakangi kerumunan orang yang duduk berpanasan di tenda atau yang mengelilingi tempat tersebut. Sampai sirine polisi terdengar mengiringi mobil-mobil mewah para pejabat mendekati tempat upacara. Dari mobil yang dikawal polisi dan tentara itu, keluarlah Putu Bagiada, Bupati Buleleng berserta pejabat pemerintah daerah Kabupaten Buleleng.

Acara formal di mulai. Seperti biasa, sambutan-sambutan dari pejabat pemerintahan tentang upacara Atma Papa, ritual yang baru terdengar dan dilaksanakan baru pertama kali di kabupaten yang terkenal "panas" dengan peristiwa kekerasan politik pada Pemilu 2004 lalu. Dari sambutan ketua panitia, keluarlah maksud dari pemerintah daerah melaksanakan upacara ini:

"Atma Papa maka piranti lan usaha ri sajeroning ngajegang adat, budaya lan agama druwene, miwah sane pinih utama prasidha nginkinang paridabdab pamargin karman atma papa nincap ke pamargin miwih linggih sane becik Sewos ring punika, ring swadharma agama lan swadharmaning negara marupa utsaha nincapang kasukerthan jagat mangda prasidha jagat druwene manggeh ajeg rawuh riwekas" (atma papa sebagai sarana dan usaha untuk ngajegang (mempertahankan, menjaga) adat, budaya dan agama kita dan yang paling utama bisa mempersiapkan perjalanan atma dan statusnya yang lebih baik. Maka dari itu, usaha dari kewajiban agama dan negara merupakan usaha

\footnotetext{
8 Seluruh narasi ini adalah hasil catatan lapangan saya menyaksikan Ritual Atma Papa di Catus Pata (perempatan) Kota Singaraja di Kabupaten Buleleng Bali pada 7 September 2004. Beberapa bagian narasi ini pernah dituliskan dalam I Ngurah Suryawan, Bali, Narasi dalam Kuasa: Politik dan Kekerasan di Bali, (Yogyakarta: Ombak, 2005).
} 
mewujudkan kedamaian dunia agar dunia kita bisa ajeg (kokoh, kuat) sampai nanti).

Ratusan sawa/adegan inilah setelah duduk berpanas-panas mendengar sambutan para pejabat, menghaturkan sembah, kemudian mengelilingi catus pata, perempatan jalan di Kabupaten Buleleng dan bersama-sama menuju setra (kuburan) desa adat Buleleng. Adegan/sawa inilah yang kemudian dibakar sebagai simbolisasi pengabenan dari roh yang belum diupacarai. Para pimpinan umat datang untuk menyaksikan upacara ini dan menghaturkan sesaji. Setelah dibakar, dilanjutkan dengan melepaskan abunya ke laut.

Antusias warga ternyata telah melalui "instruksi" dari pemerintah daerah kepada para bendesa adat (ketua adat) masing-masing banjar (desa) di Kabupaten Buleleng. Meskipun mendapat penentangan dari beberapa banjar yang tidak setuju dengan upacara ini, akhirnya secara serempak 166 desa adat/desa pakraman di Kabupaten Buleleng ikut serta dalam upacara ini. Setiap desa pakraman diwakilkan 2 adegan/sawa, sehingga jumlah adegan/sawa seluruhnya menjadi 332. Banjar yang menolak merasa upacara ini hanyalah proyek dari pemerintah untuk menghabiskan anggaran belanja daerah dan mengokohkan kepemimpinan Bupati Putu Bagiada.

Maka jangan heran jika seluruh krama (warga) desa adat yang "diharuskan" hadir dalam upacara ini tidak mengetahui apa yang harus dilakukan dan untuk apa upacara ini dilakukan. Dalam pengarahan-pengarahan ketua adat pada warganya, upacara atma papa ini adalah upacara pembersihan roh-roh yang kematiannya sampai saat ini belum diupacarai. Sama seperti keterangan resmi pejabat pemerintah, roh-roh yang gentayangan tersebut sangat berpotensi untuk merusak dan menghancurkan kehidupan manusia. Untuk itulah dilakukan upacara pembersihan atma-atma ini. Dari Bupati justru keluar pernyataan yang tegas, "Upacara ini untuk membersihkan Buleleng dari rohroh jahat yang ada selama ini dan belum diupacarai. Ini kita lakukan untuk ajeg Buleleng," katanya mantap.

Berbagai tragedi kemanusiaan bencana alam, perang dan kekerasan yang menelan korban manusia adalah sumber dari korban-korban yang belum diketahui identitasnya. Banyak nyawa yang melayang tanpa keluarga dan handai taulan mengetahui dimana jenazahnya. Maka atas inisiatif desa adat dan negara, dilakukanlah upacara pembersihan terhadap roh-roh mereka. Khusus untuk Buleleng, perang puputan Jagaraga saat melawan 
Kolonial Belanda sangat banyak menelan korban jiwa, belum lagi ditambah tragedi bencana alam dan yang tidak terlupakan, kekerasan politik saat tahun 1965, saat manusia Bali saling bunuh antara saudaranya sendiri. Banyak warga yang bungkam ketika ditanya atma yang diupacarai adalah korban dari kekerasan politik Gestok di Buleleng. Rata-rata mereka menjawab, setelah mepeluasan (bertanya pada orang pintar), ada leluhurnya yang tidak mempunyai jalan untuk ke sorga, untuk itu perlu diupacarai. Bagi mereka, korban pembantaian ' 65 di Buleleng sudah diupacarai sebelumnya bersama dengan korban bencana alam dan peperangan.

Ngaben Atma Papa adalah ngaben massal bagi jenazah yang belum diupacarai atau tidak diketahui jasadnya yang meninggal tidak wajar, tidak dikenal atau tidak diperlakukan sebagai mestinya menurut ajarah agama Hindu. Karena kematiannya yang tidak wajar, maka arwahnya menjadi tidak tenang, sengsara, dan tidak mendapat tempat untuk menuju Tuhan. Sebab kematiannya diantaranya karena tragedi politik dan bencana alam sering disebut sebagai mati salahpati (kecelakaan, dll.) dan ulahpati (bunuh diri). Ngaben Atma Papa termasuk ngaben massal dengan tingkatan nistaning utama dari tiga tingkatan yaitu nista, madya, utama. Sementara selain ngaben massal, terdapat juga ngaben sarat, ngaben sederhana, ngaben ngerit, ngaben ngegalung. ${ }^{9}$

Rangkaian Ngaben Atma Papa terdiri dari 21 rentetan ritual ${ }^{10}$ dengan maksud dan tujuannya masing-masing yaitu: mejauman (persembahan kepada pendeta yang akan menghaturan ritual), mecaru alaning dewasa (memohon waktu yang tepat), newasin lan nancep (mengatur posisi tempat ritual), ngulapin (menghias sawa/adengan pada masing-masing desa), meseh lawang (membersihkan kehidupan lama ke yang baru di catus pata, tempat ritual atma papa), mebersih (membuat sawa/adegan kemudian membersihkannya), mendak sawa lan menapak (memanggil roh dan perubahan status dari ruh biasa menuju ruh yang siap disucikan), ngaskara dan narpana (ritual di tempat sawa/adengan), manah tirta (penyucian sawa/adegan di tempat pendeta), mabhumi sudha (permohonan pembakaran sawa/adegan di kubur-

${ }^{9}$ Sutama, I Putu, "Upacara Ngaben Atma Papa di Kabupaten Buleleng: Kajian Fungsi dan Makna," Tesis, Program Magister Ilmu Agama dan Kebudayaan Universitas Hindu Indonesia (Unhi), 2005, h. 51.

${ }^{10} \mathrm{Ibid}$. 
an), mecaru tedun sawa (ritual sebelum menurunkan sawa/adegan), nyeeb dan api dan nyupit areng (pembersihan sawa/adegan setelah menjadi abu), ngereka abu sawa (mengatur abu seperti bentuk tubuh), pekiriman (ritual mempersembahan sesajen untuk sang pitara yang sudah jadi abu), nganyut dan ngulapin di segara (ritual melepas abu pitara ke laut), ngangget don bingin nanding bubur susrusu (daun beringin untuk membuat sekah sang pitara), ngajum sekah, memedek, metapak dan narpana (men-stana-kan sang pitara dan puspa lingga (sekah), nganyut sekah dan ngulapin (ritual mengumpulkan abu-abu dan dilepas ke laut), nyegara gunung (pemujaan di laut yang mengarah ke gunung), ngatukang kesunia (ritual mengembalikan roh ke Tuhan), mesidha karya (mensucikan kembali tempat pelaksanaan ngaben).

Ngaben Atma Papa bertujuan untuk penyucian atma yaitu untuk melepaskan Sang Hyang Atma dari ikatan jasmani. Tujuan lainnya adalah sebagai upacara persembahan dimana orang yang masih hidup melakukan ritual untuk mensucikan atma yang telah meninggal sehingga terlepas dari ikatan duniawi dengan ngaben. Upacara Ngaben dilakukan agara roh dapat bersatu dengan Tuhan. Ritual Atma Papa juga berfungsi untuk mengharmoniskan alam Bali secara keseluruhan dari berbagai bencana yang menimpa. Dari rangkaian tragedi kemanusiaan tersebut, banyak roh yang sengsara ( masing sesuai dengan ajaran Hindu karena berbagai hal. Roh-roh yang papa yang belum diupacarai tersebut menjadi buta cuil (setan) yang bergentayangan yang mengganggu ketentraman manusia. Ngaben Atma Papa juga merupakan bagian ritual untuk menetralisir sejarah kelam pembantain 1965 di Bali. Manusia Bali ketika itu bagai kesurupan yang tega membunuh saudaranya sendiri.11

\section{Atma Papa: Politik, Ritual, dan Representasi Kekerasan}

Para roh-roh yang papa dalam upacara atma papa ini disamaratakan oleh negara (baca: Pemerintah Daerah Kabupaten Buleleng), dianggap semua desa di Buleleng pasti ada roh yang papa dan gentayangan. Sehingga untuk mengenerasilisasi, setiap desa diwakili oleh dua adegan/sawa laki-laki dan

11 Ibid., h. 86-87. 
perempuan. Diantar oleh ratusan warga desa, berduyun-duyunlah mereka untuk datang menghadiri upacara atma papa di perempatan kota Buleleng. Suasana meriahnya upacara ini tentu sangat berbeda ketika para keluarga korban kekerasan '65 yang harus datang sembunyi-sembunyi ke setra (kuburan) desa untuk memanggil roh keluarga mereka yang hilang ketika itu. Para warga lainnya bahkan tidak mau tahu. Ya, karena ketika itu upacara ngeteg (memanggil roh korban) dianggap hanya dilakukan keluarga yang anggotanya mati karena masuk komunis, PKI.

Ketika tahun 1965, upacara mengantar kepergian roh korban yang tidak ditemukan mayatnya berlangsung hanya di antara keluarga. Ketika suami, ayah atau sanak keluarga mereka dikabarkan telah luas ke Jawa (pergi ke Jawa), istilah untuk memberikan kesan tidak ada harapan lagi pada keluarga dan bisa dipastikan anggota keluarga mereka telah terbunuh, entah dimana. Sejak mendengar kabar itulah, para keluarga korban berinisiatif menanyakan dimana tempat anggota keluarga mereka dibunuh. Itu pun kalau diketahui. Kalau tidak, pihak keluarga akan mencari informasi dan mendatangi kuburan-kuburan desa terdekat untuk memanggil roh korban untuk diaben tanpa mayat, hanya dengan simbol adegan/sawa seperti yang dilakukan saat upacara atma papa.

Tapi, yang berbeda, ketika para keluarga melakukan upacara pengabenan tanpa mayat itu, pemerintah, negara belum sepenuhnya mendukung. Pedih dan derita tentu tidak bisa dihapuskan dari para keluarga korban. Sikap pasrah juga mengundang tanya akan dimana jenazah anggota keluarga kami? Dimana ia dikuburkan? Dimana dan siapa yang membunuh? Atau pertanyaan lain yang tidak akan mungkin dijawab oleh negara. Yang bisa dilakukan negera belasan tahun kemudian setelah ' 65 adalah menutup rapi cerita pedih itu dengan serangkaian upacara pembersihan bumi Bali dengan ritual megah dan mewah. Ini untuk menunjukkan tanggung jawab negara terhadap masyarakatnya. Sementara negara melakukan upacara pembersihan megah, seperti juga upacara atma papa di Buleleng ini, saksi-saksi bisu pembantaian massal di Bali masih terus menyimpan kepedihan dari ingatan sosial masyarakat tentang pristiwa kekerasan dan pembantaian massal di Bali. Kuburan-kuburan massal hadir berdampingan dengan kemegahan upacara untuk melakukan pembersihan terhadap bumi Bali. Politik upacara telah menenggelamkan dan menutup rapi ingatan akan kekerasan para korban. Semuanya telah dinormalisasi kembali dengan upacara, ritual megah dan 
berwibawa untuk menutup kebenaran atas nama Tuhan, Ida Sang Hyang Widhi Wasa.

Dalam essaynya, "Monumen, Dokumen dan Kekerasan Massal" Santikarma $^{12}$ menguraikan politik representasi kekerasan dan (kuasa) budaya dalam tragedi kekerasan pembantaian massal 1965 dan Bom Bali 2002 (ritual Pamarisudha Karipubhaya). Tragedi Bom Bali diperingati dengan mendirikan monumen dan proyek "Recovery Bali", mengembalikan citra Bali. Sementara pembantaian massal sesama manusia Bali di tahun 1965 tersimpan rapi dalam selimut pariwisata budaya dan menjadi ingatan kelam para survivor yang didiamkan untuk bertutur.

Santikarma dengan mengutip Andreas Huyssen menguraikan, "Sebuah monumen bisa bermaksud mengingatkan kita, tetapi sebuah monumen juga bisa mengelabui darah korban kekerasan dengan estetika, dengan kemegahan, yang akhirnya memuaskan kita sampai kita tidak bisa bertanya lagi, sampai kita melupakan apa sebenarnya yang ada di bawah fondasi monumen. Monumen bisa membantu ingatan, tetap proses pembelajaran yang diwarisi tentang suatu peristiwa kurang begitu dalam." Monumen Lubang Buaya, misalnya, tidak memberikan suatu pencerahan akan refleksi kemanusiaan, tetapi justru sebuah kisah tentang bagaimana ingatan orang-orang bisa dihapus oleh sebuah rezim berkuasa untuk menciptakan sejarah. Lubang Buaya sama sekali tidak menyentuh rasa rendah hati untuk memetik hikmah dari sebuah kesalahan masa lampau, tetapi sebaliknya: pemujaan pada kebenaran monolitik. Monumen sejenis ini merayakan sejarah sebagai sesuatu yang kaku dan baku yang tidak bisa tergerak oleh pertanyaan atau pengalaman.

Ritual kematian Bom Bali begitu hiruk pikuk disaksikan oleh ribuan pasang mata dan liputan media massa. Tetapi, hajatan ini bukan hanya karya akar rumput. Keterlibatan negara dalam ritus tragedi bisa dibandingkan dengan kasus para korban kekerasan 1965 yang tidur pulas dalam kuburan massal tanpa pernah tersentuh oleh sesajen dan percikan air suci sang pendeta, apalgi iringan panjang prosesi disertai gamelan dan riuh suara pengusung mayat. Korban bom Kuta bukan hanya mendapat upacara kematian yang megah, tetapi perhatian dari dunia internasional, seperti keterlibatan Interpol, para ahli tim forensik, tim medis internasional, lembaga

12 Santikarma, “Monumen, Dokumen dan Kekerasan Massal.” 
swadaya lokal, dan organisasi internasional yang merebut memberikan bantuan. Mereka yang dibantai dalam kekerasan 1965, jangankan upacara, menyebut nama korban saja orang sudah menjauh. Keluarga yang ditinggalkan terpaksa melakukan upacara kematian tanpa mayat, dengan sembunyi dan perasaan penuh ketakutan. ${ }^{13}$

Tapi negara dalam kasus ritual Atma Papa berusaha merebut simpati dengan melakukan ritual pembersihan terhadap roh-roh yang "papa" tersebut melalui ritual Ngaben massal. Namun, tetap saja ritual tersebut hanya terhenti pada persoalan bagaimana menetralisir sejarah kelam dan membuat harmonis dan keseimbangan berlangsung. Seperti diungkapkan oleh Santikarma ${ }^{14}$ bahwa negara menempatkan ritual adalah aktivitas murni untuk kepentingan agama dalam rangka tawur atau ritus kurban, periode transisi siklus kehidupan menuju abad berikutnya menurut tradisi tahun caka. Menurut para birokrat, ritual berhubungan dengan makrokosmos dan mikrokosmos, bukan politik, dan agama adalah sesuatu yang jauh dari hiruk-pikuk "pembantaian 65" atau tragedi kemanusiaan lainnya yang dianggap noda hitam dalam perjalanan sejarah masyarakat Bali. Ritual Atma Papa meskipun menunjukkan niat baik untuk mengupacarai korban tragedi kemanusiaan yang "papa" ini, tapi negara tetap saja memungkiri sisi kemanusiaan penderitaan para korban dan menganggap Ngaben Atma Papa berusaha untuk melupakan ingatan kekerasan 1965 dengan melakukan ritual.

Ritual yang berelasi dengan politik adalah hal yang pasti. Dalam hal yang ekstrim politik dan ritual saling melayani. Dalam kedua kepentingan inilah kuasa menjadi pengikat mereka. Semua kekuasaan membutuhkan ritual untuk legitimasi dirinya. Dalam posisi ini, negara memberikan ruang untuk terjadinya ritual-ritual yang megah, glamour. Negara menciptakan ruang pada masyarakat untuk terus-menerus melakukan upacara-upacara yan megah tanpa henti. Support negara ini tidak tanggung-tanggung untuk menunjukkan negara berada dibelakang masyarakat dan mendukung upacara yang dilakukan masyarakat. Meriah dan megahnya upacara menjadi cerita dan keseharian orang Bali. Pembangunan pura mengundang pejabat dan pemerintah daerah untuk peletakan batu pertama. Upacara Ngenteg Linggih,

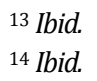


Memungkah, Ngusaba Desa, Ngusaba Nini dan lainnya mengundang pejabat untuk memberikan sambutan. Dalam sambutan ini, si pejabat bahkan langsung menyerahkan bantuan puluhan juta rupiah. Masyarakat senang dan menyabutnya dengan meriah. Berikutnya, dharma wacana (petuah-petuah) membahas perilaku upacara, tidak boleh seperti ini, tidak boleh seperti itu. Ini upacara yang benar, itu salah berulangkali terdengar. Petuah-petuah itu menjadi menarik diselingi dengan guyonan segar, seperti pertunjukan lawak bukan dharma wacana.

TV lokal (baca: Bali TV) menyadari pasar untuk masyarakat "penggemar" upacara ritual, bahkan membuat program khusus Nangun Yadnya (menyambut persembahan suci pada Tuhan/upacara ritual) dan tayangan berseri petuah-petuah dari pedanda (pemimpin umat Hindu) yang digemari karena leluconnya dan "disiplin" dalam beragama. Diundangnya pejabat dalam menyaksikan upacara adalah ukuran dari kewibawaan, status. Juga bagaimana kemegahan upacara di rancang adalah perwujudan dari kemampuan dan derajat serta posisi di masyarakat. Ritual-ritual yang menjadi musim di Bali menunjukkan bagaimana beragama, bermasyarakat diwujudkan dengan tingkah sosial masyarakatnya dalam melakukan upacara.

Ritual adalah jantung kebudayaan Bali yang kemudian berada di tangan negara sebagai ruang untuk kontestasi. Di dalamnya gugatan, konflik meletus kepermukaan, tapi pada saat yang bersamaan solidaritas, konsensus dan kebersamaan juga mencuat. Ruang-ruang ambiguitas inilah yang diinginkan oleh negara pada masyarakatnya. Pada saat tertentu timbul gugatan, tapi pada saat yang lain timbul juga solidaritas dan kebersamaan untuk mendukung upacara. Politik ritual seperti ini melibatkan pemain-pemain budaya Bali menjadi pion-pion dan penghubungnya. Pejabat pemerintah, elite dan broker politik bahkan pejabat adat di desa-desa.

Rentetan ritual yang berelasi dengan politik tiada terhitung jumlahnya di Bali. Dan kini ritual memang tidak bisa dipandang hanya sebagai ritus harmoni sosial, penyeimbang kehidupan yang sedang "goyah", atau untuk berYadnya (berkorban suci). Ritual pembersihan kekerasan '65, pembersihan arwah yang "papa" dalam tragedi kekerasan dalam ritual Atma Papa adalah sedikit contoh. Tahun 1963 dan dilanjutkan pada tahun 1979, berlangsung perhelatan ritual agung di Bali yaitu Eka Dasa Rudra yang dilaksanakan di Pura Besakih. Upacara ini untuk membersihkan nyawa manusia yang 
melayang karena bencana alam letusan Gunung Agung 1963 dan pembantaian G30S tahun 1965-1966. Saat upacara itulah dilakukan rangkaian upacara nyapuh jagad, upacara pembersihan dunia, dari musibah, bencana alam yang disebabkan oleh kala (Dewa Kejahatan). Termasuk dalam upacara nyapuh jagad ini adalah pembersihan para korban pembantaian PKI yang mayatnya sudah ataupun belum ditemukan. Upacara ini meskipun disponsori oleh negara dan PHDI, tidak sesemarak dan mendapat liputan internasional seperti upacara Mapharisudha Karipubhaya.

Dalam konteks ini, upacara bukan hanya menjadi alasan tertib kosmis, keseimbangan alam yang sering terdengar dalam ceramah-ceramah agama, tapi juga bisa menjadi total relasi dari kepentingan negara/pemerintah daerah dan lembaga umat PHDI dengan masyarakat sebagai pengayah-nya (pelayannya) dalam upacara-upacara besar keagamaan. Jika pada zaman kolonial, raja-raja di Bali menjadi patron kuat kekuasaan bagi abdinya. Semua relasi kekuasaan itu ditujukan ke arah pertunjukan, upacara, ke arah dramatisasi di muka umum dari obsesi-obsesi utama budaya Bali; derajat sosial dan kebanggaan status (baca: relasi kuasa). Geertz ${ }^{15}$ melatakkan dasar awal bagaimana upacara, negara, masyarakatnya kemudian berelasi kuat sampai saat ini dengan kekusaan yang ada dalam "imaji", dalam bayang-bayang. Akhirnya, kekuasaan melayani upacara dan juga pada titik tertentu upacara juga melayani kekuasaan.

Politik ritual adalah usaha untuk pengilmiahan, peniskalaan kekuasaan dalam bingkai upacara yang dilakukan Orde Baru. Orde Baru juga secara cerdik memainkan ritual menjadi instrumen untuk kembali merekatkan kebersamaan, dimana kemudian negara mensubversinya untuk menambah energi sosial masyarakat yang bisa dimanfaatkan untuk kepentingankepentingan politik para petualang-petualang kekuasaan dan pemain budaya Bali. Dalam politik ritual, negara juga menormalkan, mengharmoniskan situasi yang terjadi di masyarakat. Meminjam Michael Foucault, usaha yang paling cerdik dilakukan negara adalah bagaimana mengkondusifkan relasirelasi kekuasaan oleh negara. Berbagai macam pertentangan/konflikdilakukan oleh kelompok politik komunal soroh (keturunan dari garis darah yang banyak jumlahnya di Bali) dalam upacara-merupakan bagian inhern

15 Geertz, Clifford, Kebudayaan dan Agama, (Yogyakarta: Penerbit Kanisius, 1992). 
dalam relasi kekuasaan yang dibangun, yang cenderung untuk mengisolasikan dan mengindividuasikan perlawanan menjadi serangkaian "kasus-kasus khusus" yang tidak mengizinkan generalisasi.

Upacara selain melahirkan keakraban komunal, juga mematik konflik. Dengan discourse kekuasaan yang dibentuk negara, maka dilakukanlah intervensiintervensi dengan resep standarisai upacara-upacara yang dilakukan oleh pemangku dan pedanda di Bali. Akhirnya, politik komunalitas yang diciptakan negara didukung penuh dengan rangkaian riuh rendah dan glamour upacaraupacara besar keagamaan yang dikreasi sepenuhnya oleh negara. Kreasi politik ritual ini terlihat jelas dari bagaimana intervensi negara dalam pelaksanaan upacara Atma Papa di Kabupaten Buleleng. Desa-desa yang menolak upacara ini adalah sebagian kecil masyarakat yang tidak mempunyai kekuatan sama sekali untuk menghambat jalannya upacara. Upacara berlangsung meriah dan sukses. Desa yang menolak itu adalah kasus kecil dalam masyarakat. Stabilitas, standarisasi dan harmonisasi yang diciptakan oleh negara menunjukkan bagaimana ritual dikreasi untuk kepentingan politik.[w] 


\section{BIBLIOGRAFI}

Dhafamony, Mariasusai, Fenomenologi Agama, Yogyakarta: Kanisius, 1995

Geertz, Clifford, Kebudayaan dan Agama, Yogyakarta: Kanisius, 1992.

Kartodirdjo, Sartono (ed.), Kepemimpinan dalam Dimensi Sosial, Jakarta: LP3ES, 1984.

“Ngaben Bermasalah Kremasi Sajalah," Majalah Sarad No. 68 Desember 2005.

Palguna, IBM., Dharma, Bom Teroris dan "Bom Sosial," Narasi dari Balik Harmoni Bali: Perspektif Korban dan Relawan, Denpasar: Yayasan Kanaivasu, 2006.

Santikarma, Degung, "Monumen, Dokumen dan Kekerasan Massal," Kompas, 1 Agustus 2003.

Santikarma, Degung, "Sweeping” Bali, 'Sekala" dan "Niskala," Kompas, 7 April 2004.

Suhardi, "Ritual: Pencarian Jalan Keselamatan Tataran Agama dan Masyarakat Perspektif Antropologi," Pidato Pengukuhan Guru Besar Antropologi pada Fakultas Ilmu Budaya Universitas Gadjah Mada, 18 Maret 2009.

Sujaya, I Made, Sepotong Nurani Kuta: Catatan Seputar Sikap Warga Kuta dalam Tragedi 12 Oktober 2002, Denpasar: Lembaga Pemberdayaan Masyarakat (LPM) Kuta, 2004.

Suryawan, I Ngurah, BALI, Narasi dalam Kuasa (Politik dan Kekerasan di Bali), Yogyakarta: Penerbit Ombak, 2005.

Sutama, I Putu, "Upacara Ngaben Atma Papa di Kabupaten Buleleng: Kajian Fungsi dan Makna," Tesis Program Magister Ilmu Agama dan Kebudayaan Universitas Hindu Indonesia (Unhi), 2005. 